\title{
Income inequality and carbon dioxide emissions: The case of Chinese urban households
}

\author{
Jane Golley ${ }^{\mathrm{a}, *}$, Xin Meng ${ }^{\mathrm{b}}$ \\ a Australian Centre on China in the World, College of Asia and Pacific, Australian National University, Canberra, ACT 0200, Australia \\ ${ }^{\mathrm{b}}$ Research School of Economics, College of Business and Economics, Australian National University, Canberra, ACT 0200, Australia
}

\section{A R T I C L E I N F O}

Article history:

Received 28 July 2012

Accepted 28 July 2012

Available online 17 August 2012

\section{JEL classifications:}

D12

D30

D57

Q42

Q56

R20

\section{Keywords:}

Income inequality

Carbon dioxide emissions

Household consumption

Urban China

\begin{abstract}
A B S T R A C T
This paper draws on Chinese survey data to investigate variations in carbon dioxide emissions across households with different income levels. Rich households generate more emissions per capita than poor households via both their direct energy consumption and their higher expenditure on goods and services that use energy as an intermediate input. An econometric analysis confirms a positive relationship between emissions and income and establishes a slightly increasing marginal propensity to emit (MPE) over the relevant income range. The redistribution of income from rich to poor households is therefore shown to reduce aggregate household emissions, suggesting that the twin pursuits of reducing inequality and emissions can be achieved in tandem.
\end{abstract}

Crown Copyright @ 2012 Published by Elsevier B.V. All rights reserved.

\section{Introduction}

China's recent rise to the unenviable position as the world's largest emitter of carbon dioxide has coincided with a far more enviable economic growth record during the last three decades, albeit one that has generated significant income inequalities in a range of dimensions. Chinese leaders are challenged by the simultaneous needs to 'build a resource efficient and environmentally-friendly society' and to ensure that growth is more equitable, both of which are integral to 'building a harmonious society' as outlined in the Eleventh Five-Year Plan (2006-2010) and reiterated in the Twelfth Five-Year Plan (2011-2015). It is far from obvious how best to tackle this combination of challenges from a policy perspective, even when narrowing the analysis down to a particular disadvantaged region, sector or group within the Chinese economy. Transferring income from rich to poor households, for example, would obviously reduce inter-household income inequality, but what would be the consequences for the aggregate carbon dioxide emissions of Chinese households (let alone of China at large)? Policy decisions would be considerably easier to make if income redistribution turned out to be environmentally friendly as well.

\footnotetext{
* Corresponding author. Tel.: +6126125 3366.

E-mail address: jane.golley@anu.edu.au (J. Golley).
}

This paper demonstrates that this may well be the case for China's urban household sector. To establish this point, we utilize China's Urban Household Income and Expenditure Survey (UHIES) 2005 to investigate variations in per capita carbon dioxide emissions (henceforth emissions $^{1}$ ) across urban households with different income levels. ${ }^{2}$ Cross-country time-series analyses of the relationship between emissions and income have provided evidence of a diminishing marginal propensity to emit (MPE) as income rises (Heil and Selden, 2001; Holtz-Eakin and Selden, 1995; Ravallion et al., 2000). Critically, as shown by Ravallion et al. (2000), a diminishing MPE implies a trade off between inequality-improving income redistributions and aggregate carbon dioxide emissions, whereas an increasing MPE implies a win-win case in which inequality reductions go hand in hand with aggregate emission reductions.

\footnotetext{
1 All subsequent reference to "emissions" in this paper implies "carbon dioxide emissions". By focusing on carbon dioxide only, we overlook other greenhouse gasses (GHGs), such as methane, nitrous oxide and chlorofluorocarbons. While these other GHGs may be equally, or even more, important for certain environmental problems, data restrictions prevent a more holistic analysis at this stage.

2 The UHIES was conducted by the National Bureau of Statistics in 31 provinces. The data we have access to cover 16 provinces. The survey only samples urban permanent households (households with urban household registration or hukou).
} 
Ravallion et al. (2000: p. 653) acknowledge that consumer demand is 'the most likely source of non-linearities in the effect of higher incomes on emissions, particularly given that the latter depend in large part on what goods are consumed within the economy'. They also make the critical observation that direct consumer demand for energy (i.e. fossil fuels) is only part of the story since 'many goods which do not require fossil fuel combustion as part of their consumption do require it for production. Both the direct and indirect demands are relevant to carbon emissions' (p. 653). Yet after making this observation, they then use estimates of national-level emissions based on fossil fuel use and cement production to calculate per capita emissions, which do not take consumers' indirect energy demand into account. Taking a consumer-based approach, numerous recent studies have highlighted how important this indirect energy consumption-and hence indirect emissions generation-can be. Wei et al. (2007), for example, attempt to quantify the direct and indirect energy requirements and related carbon emissions of Chinese urban and rural residents between 1999 and 2002, and show that $71 \%$ of urban household energy is consumed indirectly. Pachauri and Spreng (2002) show that indirect energy requirements account for close to half of the total energy consumption of Indian households, while Cohen et al. (2005) show that $61 \%$ of household energy is indirectly consumed in Brazil. ${ }^{3}$ When a more comprehensive measure of indirect emissions is included in each consumer's total emissions, it is far from clear that the MPE will still be diminishing, whether in cross-country time-series or single country cross-sectional analyses. ${ }^{4}$

The paper is structured as follows. Section 2 describes the methodology and data used to calculate each household's per capita energy consumption and emissions and presents the key results depicting the relationship between these two variables and per capita income. Our econometric analysis is presented in Section 3, followed by a consideration of the impact of income redistribution on aggregate household emissions in Section 4. Section 5 concludes.

\section{Per capita energy consumption and emissions of Chinese urban households}

Emissions are embodied in energy, which each household consumes directly, in the form of coal, petroleum, natural gas and electricity, and indirectly via the energy inputs used in the production of all other goods and services that the household consumes. ${ }^{5}$ Each household's direct energy consumption is relatively easy to calculate, as long as the physical quantity of consumption of each direct energy source can be observed. These physical quantities can be converted into net calorific values (expressed in joules) and summed across all sources. Each of these energy sources has a different emission factor, which is country and sector specific. Each household's direct energy consumption can thus be converted into its direct emissions by multiplying the net calorific value of each energy source by its emission factor and summing across all sources.

'Indirect' energy consumption, and therefore indirect emissions, can be calculated in a number of ways. Process analysis assesses the emissions generated throughout the lifecycle of a product, from the commencement of production through to distribution, storage, transport, waste and recycling. This method appears to have been used

\footnotetext{
${ }^{3}$ See also Kerkhof et al. (2009) on the Netherlands, UK, Sweden and Norway, Lenzen et al. (2006) on Australia, Brazil, Denmark, India and Japan, Baiocchi et al. (2010) on the UK, and Lenzen et al. (2004) on Sydney.

${ }^{4}$ This is not to suggest that Ravallion et al. (2000) should have tried to do this. Given the effort and data required to construct household-level indirect energy and emissions data for a single country in a single year, compiling accurate and consistent cross-country time series data of this kind simply isn't an option. Kerkhof et al.'s (2009) four-country, two-year comparative analysis is impressive enough.

${ }^{5}$ The definition of 'direct' energy requirements used here excludes biomass fuels such as firewood and crop stalks, which constitute a major source of energy in developing, rural areas: according to Pachauri and Jiang (2008), 60\% of rural Chinese use traditional biomass fuels for their heating and cooking needs. However, they also note that urban Chinese households-the focus of this paper-use almost no biomass fuels, so this definition seems appropriate in this case.
}

only for European analysis where such detailed data is available. ${ }^{6}$ Less data-intensive methods rely on input-output (IO) analysis to identify the energy embodied in a unit value of production for each sector. The resulting embodied energy intensities reflect not only the energy used as direct inputs into the production of each good, but also the energy used in the intermediate inputs that are used in the production of that good, and the energy used in the intermediate inputs of those intermediate inputs, and so on. ${ }^{7}$ These sector-level intensities can be combined with household expenditure on each sector to calculate the indirect energy consumption of each household, in what Kok et al. (2006) call the 'IO plus household expenditure' method. ${ }^{8}$ This method is much more commonly used for practical reasons and is the method adopted here.

In particular, household $k$ 's total energy consumption per capita is the sum of its direct energy consumption per capita and its indirect energy consumption per capita. In order to calculate the latter, we first calculate the direct energy intensities associated with each sector and then use IO data to calculate the associated indirect energy intensities, which are given by:

$\mathbf{I}^{\mathbf{E}}=\mathbf{D}^{\mathbf{E}}(\mathbf{I}-\mathbf{A})^{-1}$

where $\mathbf{I}^{\mathbf{E}}$ is a vector of indirect energy intensities in each sector, $\mathbf{D}^{\mathbf{E}}$ is a vector of direct energy intensities in each sector and $\mathbf{A}$ is the interindustry matrix of direct input coefficients. Given the 42 sector IO data used below, $\mathbf{A}$ is a 42 by 42 matrix of direct input coefficients, where $a_{i j}(i, j=1,2, \ldots ., 42)$ is the value of industry $i$ used in the production of one yuan of industry $j$ 's output. Multiplying the Leontief inverse matrix $(\mathbf{I}-\mathbf{A})^{-\mathbf{1}}$ by the direct energy intensity vector, $\mathbf{D}^{\mathbf{E}}$, yields a vector of indirect energy intensities for each sector. In turn, multiplying $\mathbf{I}^{\mathbf{E}}$ by a vector of household expenditure per capita on each good, $\mathbf{y}_{\mathbf{k}}$, gives each household's indirect energy consumption per capita. Thus household $k$ 's total energy consumption per capita can be expressed as:

$T E_{k}=D E_{k}+I E_{k}=\sum_{i=1}^{4} D E_{i k}+\mathbf{I}^{\mathbf{E}^{\prime}} \mathbf{y}_{\mathbf{k}}$

where $D E_{k}$ and $I E_{k}$ are household $k$ 's direct and indirect energy consumption per capita respectively and $D E_{i k}$ is household $k$ 's direct consumption of energy $i$ per capita.

Likewise, in order to calculate indirect emissions, we first need to calculate the direct and indirect emission intensities associated with each good:

$\mathbf{I}^{\mathbf{C}}=\mathbf{D}^{\mathbf{C}}(\mathbf{I}-\mathbf{A})^{-1}$

where $\mathbf{I}^{\mathbf{C}}$ is a vector of indirect emission intensities in each sector and $\mathbf{D}^{\mathbf{C}}$ is a vector of direct emission intensities in each sector. Household $k$ 's total emissions per capita can then be expressed as:

$T C_{k}=D C_{k}+I C_{k}=\sum_{i=1}^{4} f_{i} D E_{i k}+\mathbf{I}^{\mathbf{C}^{\prime}} \mathbf{y}_{\mathbf{k}}$

where $D C_{k}$ and $I C_{k}$ are direct and indirect emissions per capita respectively and $f_{i}$ is the emission factor for energy $i$.

\footnotetext{
${ }^{6}$ See Reinders et al. (2003) for example.

7 In contrast, Wei et al. (2007) appear to use only the direct energy inputs in the production of each good in their intensity calculations, which they then use to calculate each consumer's indirect energy consumption. By ignoring the IO table, this method understates the importance of indirect emissions. This less comprehensive method was also used in Golley et al. (2008).

8 To complicate matters, different authors use different names for the same method. For example, Kok et al.'s 'IO plus household expenditure' method is Bin and Dowlatabadi's (2005) 'environmental IO life-cycle analysis' and Weber and Perrels's (2000) 'mixed monetary energetic approach'. This is basically the method used by Pachauri and Spreng (2002), Pachauri (2004), Cohen et al. (2005), and Kerkhof et al. (2009), among others.
} 
Table 1

Direct and indirect energy and carbon intensities by sector; 2005.

Source: Authors' calculations using method and data described in this section.

\begin{tabular}{|c|c|c|c|c|}
\hline & $\begin{array}{l}\text { Direct energy indirect } \\
\text { (MJ/yuan) } \\
\mathbf{D}^{\mathbf{E}}\end{array}$ & $\begin{array}{l}\text { Indirect energy intensity } \\
\text { (MJ/yuan) } \\
\mathbf{I}^{\mathbf{E}}\end{array}$ & $\begin{array}{l}\text { Direct carbon intensity } \\
\text { (kg/yuan) } \\
\text { D }^{\mathbf{C}}\end{array}$ & $\begin{array}{l}\text { Indirect carbon intensity } \\
\text { (kg/yuan) } \\
\mathbf{I}^{\mathbf{C}}\end{array}$ \\
\hline Manufacture of food products and tobacco processing & 0.233 & 1.944 & 0.017 & 0.174 \\
\hline Textile goods & 0.280 & 2.973 & 0.019 & 0.263 \\
\hline Wearing apparel, leather, furs and down & 0.364 & 2.623 & 0.025 & 0.230 \\
\hline Sawmills and furniture & 0.170 & 2.916 & 0.012 & 0.274 \\
\hline Paper and products, printing and record medium reproduction & 0.408 & 3.278 & 0.029 & 0.297 \\
\hline Petroleum processing and coking & 0.874 & 3.945 & 0.063 & 0.333 \\
\hline Chemicals & 0.516 & 4.620 & 0.055 & 0.434 \\
\hline Metal products & 0.151 & 4.230 & 0.009 & 0.506 \\
\hline Machinery and equipment & 0.168 & 3.645 & 0.013 & 0.423 \\
\hline Transport equipment & 0.136 & 3.312 & 0.010 & 0.375 \\
\hline Electric equipment and machinery & 0.062 & 3.525 & 0.004 & 0.413 \\
\hline Electronic and telecommunication equipment & 0.038 & 3.141 & 0.002 & 0.347 \\
\hline Instruments, meters, cultural and office machinery & 0.037 & 3.121 & 0.002 & 0.347 \\
\hline Other manufacturing products & 0.183 & 2.909 & 0.011 & 0.291 \\
\hline Electricity, steam and hot water production and supply & 12.680 & 16.194 & 1.066 & 1.394 \\
\hline Gas production and supply & 1.450 & 4.988 & 0.095 & 0.412 \\
\hline Water production and supply & 0.233 & 5.034 & 0.007 & 0.437 \\
\hline Construction & 0.096 & 3.497 & 0.007 & 0.425 \\
\hline Transports and storage & 1.689 & 3.790 & 0.120 & 0.312 \\
\hline Post, telecommunication and IT services & 0.152 & 2.263 & 0.010 & 0.223 \\
\hline Wholesale and retail trade & 0.229 & 1.248 & 0.015 & 0.111 \\
\hline Eating and drinking places, and hotels & 0.229 & 2.061 & 0.015 & 0.181 \\
\hline Finance and insurance & 0.152 & 1.264 & 0.010 & 0.115 \\
\hline Real estate & 0.152 & 0.819 & 0.010 & 0.078 \\
\hline Rentings and other commercial services & 0.152 & 2.478 & 0.010 & 0.247 \\
\hline Residential and other services & 0.152 & 1.907 & 0.010 & 0.176 \\
\hline Education & 0.152 & 1.913 & 0.010 & 0.175 \\
\hline Health services and social welfare & 0.152 & 3.208 & 0.010 & 0.302 \\
\hline Culture, sports and entertainments & 0.152 & 1.901 & 0.010 & 0.174 \\
\hline
\end{tabular}

Our data is drawn from a variety of sources. China's Urban Household Income and Expenditure Survey (UHIES) 2005 provides details of household-level expenditure on 131 goods and service items, from which we calculate per capita expenditures by dividing through by the number of household members. ${ }^{9}$ UHIES also provides household-level consumption quantities of coal, petroleum, natural gas and electricity, ${ }^{10}$ which are converted into kilojoules using the conversion factors provided in Peters et al. (2006) and again divided by the number of household members to obtain per capita values. Emission factors for each of these energy sources in China's urban sector are used to translate direct energy into direct emissions, and are also drawn from Peters et al. (2006). For the indirect energy and emissions, we first aggregate the survey data into the sectors provided in China's 42 sector $2005 \mathrm{IO}$ table. This is combined with energy and emissions data for 44 sectors in 2005 , which are compiled by Peters et al. (2006), to calculate direct energy and emission intensities for 42 sectors, from which the indirect energy and emissions follow. ${ }^{11}$ See Appendix A for further details.

\footnotetext{
${ }^{9}$ Please see Appendix A for further details on our measure of expenditure.

10 Thus our measure of "direct" energy at the household level therefore includes both primary (coal, petroleum and natural gas) and secondary (electricity) energy sources. Note that "direct" energy at the sectoral level is Peters et al.'s (2006) "total energy consumption" for each sector, which is calculated from the final allocation of each fuel type. This includes primary energy (aggregated into coal, natural gas and petroleum) and secondary energy (in the form of heat and electricity), with adjustments for losses and transformation taken into account in the latter. There are more comprehensive ways to measure the emissions embodied in electricity, that take into account electrical line losses and the mix of power plants in each city, reflecting also the mix of supplies from local and imported sources. See Kennedy et al. (2010) for details.

11 This approach implicitly assumes that imported goods consumed by Chinese households have the same energy and emission intensities as goods produced domestically, which is very unlikely to be the case in practice. A growing body of literature is addressing this problem-see for example, Weber and Matthews (2008) and Druckman and Jackson (2009)-but it falls beyond the scope of this paper to deal with it here.
}

Table 1 presents the direct and indirect energy and emission intensities for each sector that is consumed by households, expressed in megajoules (MJ) and kilograms per yuan respectively. Two key points emerge. First, as expected, there are substantial differences in the direct energy and emission intensities across different sectors, with the latter ranging from over a kilogram per yuan in the electricity, steam and hot water sector to just $2 \mathrm{~g} /$ yuan in the electronic and telecommunications equipment sector. Second, there are generally substantial differences between the values of direct and indirect intensities. The construction sector, for example, ranks fourth last in direct emissions at $7 \mathrm{~g} /$ yuan but eighth in terms of indirect emissions of $0.425 \mathrm{~kg}$. The electronic and telecommunications equipment sector, the electric equipment and machinery sector and the instruments,

Table 2

Household per capita energy consumption and emissions by income decile. Source: Authors' calculations using method and data described in this section.

\begin{tabular}{|c|c|c|c|c|c|c|c|c|}
\hline \multirow[t]{2}{*}{ Decile } & \multirow{2}{*}{$\begin{array}{l}\text { Total } \\
\text { energy } \\
(T E) \\
(\mathrm{MJ})\end{array}$} & \multicolumn{2}{|c|}{$\begin{array}{l}\text { Direct } \\
\text { energy } \\
(D E)\end{array}$} & \multirow{2}{*}{$\begin{array}{l}\text { Indirect } \\
\text { energy } \\
(I E) \\
(\mathrm{MJ})\end{array}$} & \multirow{2}{*}{$\begin{array}{l}\text { Total } \\
\text { emissions } \\
(T C) \\
(\mathrm{kg})\end{array}$} & \multicolumn{2}{|c|}{$\begin{array}{l}\text { Direct } \\
\text { emissions } \\
(D C)\end{array}$} & \multirow{2}{*}{$\begin{array}{l}\text { Indirect } \\
\text { emissions } \\
\frac{(I C)}{(\mathrm{kg})}\end{array}$} \\
\hline & & $(\mathrm{MJ})$ & $\begin{array}{l}(\% \text { of } \\
\text { total })\end{array}$ & & & $(\mathrm{kg})$ & $\begin{array}{l}(\% \text { of } \\
\text { total) }\end{array}$ & \\
\hline 1 & 12,893 & 6134 & 48 & 6759 & 1029 & 406 & 39 & 623 \\
\hline 2 & 16,103 & 6323 & 39 & 9780 & 1316 & 410 & 31 & 907 \\
\hline 3 & 18,408 & 6496 & 35 & 11,912 & 1524 & 415 & 27 & 1109 \\
\hline 4 & 19,989 & 6232 & 31 & 13,756 & 1673 & 391 & 23 & 1282 \\
\hline 5 & 22,845 & 6587 & 29 & 16,258 & 1937 & 412 & 21 & 1525 \\
\hline 6 & 25,022 & 6662 & 27 & 18,360 & 2139 & 413 & 19 & 1726 \\
\hline 7 & 28,376 & 6984 & 25 & 21,392 & 2450 & 430 & 18 & 2020 \\
\hline 8 & 31,636 & 7066 & 22 & 24,570 & 2757 & 431 & 16 & 2327 \\
\hline 9 & 37,069 & 7614 & 21 & 29,455 & 3258 & 463 & 14 & 2795 \\
\hline 10 & 58,157 & 9356 & 16 & 48,802 & 5334 & 576 & 11 & 4758 \\
\hline Total & 27,050 & 6945 & 26 & 20,104 & 2342 & 435 & 19 & 1907 \\
\hline
\end{tabular}


Table 3

Per capita direct energy consumption and emissions by energy source.

Source: Authors' calculations using method and data described in this section.

\begin{tabular}{|c|c|c|c|c|c|c|c|c|c|}
\hline \multirow[t]{2}{*}{ Decile } & \multicolumn{3}{|l|}{ Coal } & \multicolumn{3}{|c|}{ Coal emissions } & \multirow{2}{*}{$\frac{\text { Oil emissions }}{\left(\mathrm{kg} \text { of } \mathrm{CO}_{2}\right)}$} & \multirow{2}{*}{$\frac{\text { Electricity emissions }}{\left(\mathrm{kg} \text { of } \mathrm{CO}_{2}\right)}$} & \multirow{2}{*}{$\frac{\text { Gas emissions }}{\left(\mathrm{kg} \text { of } \mathrm{CO}_{2}\right)}$} \\
\hline & $(\mathrm{MJ})$ & (\% of total) & (\% of direct) & $\left(\mathrm{kg}\right.$ of $\left.\mathrm{CO}_{2}\right)$ & (\% of total) & (\% of direct) & & & \\
\hline 1 & 3369 & 26 & 55 & 244 & 24 & 60 & 23 & 51 & 87 \\
\hline 2 & 2792 & 17 & 44 & 202 & 15 & 49 & 33 & 62 & 112 \\
\hline 3 & 2431 & 13 & 37 & 176 & 12 & 42 & 41 & 71 & 126 \\
\hline 4 & 1835 & 9 & 29 & 133 & 8 & 34 & 42 & 80 & 136 \\
\hline 5 & 1798 & 8 & 27 & 130 & 7 & 32 & 49 & 87 & 146 \\
\hline 6 & 1459 & 6 & 22 & 106 & 5 & 26 & 57 & 95 & 156 \\
\hline 7 & 1292 & 5 & 19 & 94 & 4 & 22 & 62 & 103 & 170 \\
\hline 8 & 1060 & 3 & 15 & 77 & 3 & 18 & 62 & 113 & 179 \\
\hline 9 & 904 & 2 & 12 & 66 & 2 & 14 & 81 & 124 & 193 \\
\hline 10 & 625 & 1 & 7 & 45 & 1 & 8 & 163 & 158 & 210 \\
\hline Total & 1757 & 6 & 25 & 127 & 5 & 29 & 61 & 94 & 151 \\
\hline
\end{tabular}

meters, cultural and office equipment sector each have indirect emissions that are more than 100 times greater than their direct emissions. These findings reflect the importance of using the input-output method to determine the relevant intensities attributed to household consumption of each good.

Table 2 presents key summary statistics of urban households' per capita energy consumption and emissions by income decile in 2005. The table shows that the surveyed urban Chinese individuals consumed an average of 27,050 MJ of energy per annum, which in turn generated an average of $2.3 \mathrm{t}$ of emissions. According to the International Energy Agency (IEA, 2007), per capita emissions in China reached $3.9 \mathrm{t}$ in $2005 .^{12}$ Since their calculation methods are different, it is not possible to attribute a specific proportion of that $3.9 \mathrm{t}$ to households, but the figures still indicate that urban households account for a substantial share of China's emissions, and therefore that understanding trends in urban household patterns is important.

As shown in Table 2, energy consumption and emissions are increasing throughout the income range, and are much higher for richer households than for poorer ones, with those of households in the richest decile 4.5 and 5.1 times those in the poorest decile respectively. This is to be expected, since people with more income are likely to spend more on both direct and indirect energy consumption. More striking are the variations in the shares of direct and indirect energy and emissions, with the share of direct emissions dropping from $39 \%$ to $11 \%$ across the income range. This reveals that indirect emissions become an increasingly important source of total emissions as income rises. ${ }^{13}$

Table 3 focuses on the sources of direct energy consumption and emissions across income deciles. The most striking difference in direct energy consumption is the reliance on coal, with individuals in the 1st income decile consuming an average of $3369 \mathrm{MJ}$ of coal in 2005, more than five times the amount of coal consumed by individuals in the 10th decile. These large absolute discrepancies translate into large differences in the shares of alternative energy sources across income brackets, with coal accounting for $55 \%$ of the 1 st decile's direct energy compared with just $7 \%$ for the 10th decile. Because coal is the most carbon-intensive energy source (i.e., with the highest emissions factor, as shown in Table A.1), the share of emissions associated with these coal shares is even higher, accounting for $60 \%$ of the 1 st decile's direct emissions, for example. While the quantity of all other sources of energy and the emissions generated therein increase with income, the

\footnotetext{
12 This per capita figure is considerably lower if corrected for those emissions embodied in Chinese exports to the rest of the world, as discussed in Peters and Hertwich (2008) and Peters et al. (2011).

${ }^{13}$ Urban China is not alone in this, with a similar change in the ratio of direct and indirect also observed in urban Australia, for example (Lenzen et al., 2004).
}

Table A.1

Emission factors by energy source.

\begin{tabular}{llll}
\hline & $\begin{array}{l}\text { Gross emission factor } \\
(\text { kg per } \mathrm{MJ})\end{array}$ & $\begin{array}{l}\text { FOC in urban } \\
\text { sector }(\%)\end{array}$ & $\begin{array}{l}\text { Emission factor } \mathrm{f}_{\mathrm{i}} \\
(\mathrm{kg} \text { per } \mathrm{MJ})\end{array}$ \\
\hline Coal & 0.091 & 80 & 0.073 \\
Crude oil & 0.073 & 98 & 0.072 \\
Gasoline & 0.069 & 98 & 0.068 \\
Natural gas & 0.056 & 99 & 0.056 \\
Electricity & 0.073 & 81 & 0.059 \\
\hline
\end{tabular}

quantity of coal and its associated emissions are in fact decreasing with income. ${ }^{14}$

It is this fact that drives the decline in per capita total carbon intensities over the income range, falling from $0.301 \mathrm{~kg} / \mathrm{yuan}$ in the 1st decile to $0.208 \mathrm{~kg} /$ yuan in the 10 th decile. ${ }^{15}$ That is, people in poorer households are more energy intensive and therefore more carbon intensive in their total expenditure patterns. Table 4 shows that this decline is driven entirely by the decline in direct carbon intensity, since indirect carbon intensity increases slightly over the same range, as seen also in Fig. 1 using income percentiles. This is because they spend a greater proportion of their income on direct energy and also because a substantial amount of their direct energy is in the form of coal, the most carbonintensive energy source, whereas richer households shift into gas, particularly for heating and cooking purposes.

This is not to say that the sources of indirect emissions do not vary across income deciles, as shown in Table 5. Different levels of expenditure on each good, combined with different emission intensities for each sector, result in variations in the contributions of each sector to each decile's indirect and total emissions. For example, food products and tobacco account for $22.9 \%$ of the poorest decile's indirect emissions, double the share for the richest decile, while $10.6 \%$ of the richest decile's indirect emissions stem from transport equipment, compared with less than $1 \%$ for the poorest decile. In aggregate, these different consumption bundles translate into the slight increase in the (average) indirect carbon intensity as income rises, suggesting that poorer households are relatively 'green' when it comes to their indirect carbon generation.

Finally, in what follows we are primarily interested in the relationship between emissions and income and what this implies about the impact of income redistribution from rich to poor households on aggregate

\footnotetext{
14 This, in turn, is due to the fact that the price for coal is approximately one third of the price for gas, one ninth of the price for electricity, and one eleventh of the price for petrol, although of course these different energy carriers are not perfect substitutes. The average prices per ton of coal (374 yuan), gas (1070 yuan), electricity (3246) and petrol (4033) are derived from UHIES, 2005. These prices all vary across regions, which is one of the reasons why we include provincial dummies in the regression analysis below.

${ }^{15}$ Note that per capita emission intensities refer to the emissions per yuan of expenditure per person, in contrast with the sectoral-level emission intensities, which refer to the emissions per yuan of output in that sector.
} 
Table 4

Household per capita income, energy and carbon intensities.

Source: Authors' calculations using method and data described in this section.

\begin{tabular}{|c|c|c|c|c|c|c|c|}
\hline \multirow[t]{2}{*}{ Decile } & Income & $\begin{array}{l}\text { Total } \\
\text { energy } \\
\text { intensity }\end{array}$ & $\begin{array}{l}\text { Direct } \\
\text { energy } \\
\text { intensity }\end{array}$ & $\begin{array}{l}\text { Indirect } \\
\text { energy } \\
\text { intensity }\end{array}$ & $\begin{array}{l}\text { Total } \\
\text { carbon } \\
\text { intensity }\end{array}$ & $\begin{array}{l}\text { Direct } \\
\text { carbon } \\
\text { intensity }\end{array}$ & $\begin{array}{l}\text { Indirect } \\
\text { carbon } \\
\text { intensity }\end{array}$ \\
\hline & (yuan) & $\begin{array}{l}(\mathrm{MJ} / \\
\text { yuan })\end{array}$ & $\begin{array}{l}(\mathrm{MJ} / \\
\text { yuan })\end{array}$ & $\begin{array}{l}(\mathrm{MJ} / \\
\text { yuan })\end{array}$ & $\begin{array}{l}\text { (kg/ } \\
\text { yuan) }\end{array}$ & $\begin{array}{l}\text { (kg/ } \\
\text { yuan) }\end{array}$ & $\begin{array}{l}(\mathrm{kg} / \\
\text { yuan })\end{array}$ \\
\hline 1 & 3156 & 3.80 & 1.92 & 1.88 & 0.301 & 0.128 & 0.173 \\
\hline 2 & 4860 & 3.22 & 1.33 & 1.89 & 0.261 & 0.086 & 0.175 \\
\hline 3 & 6101 & 3.00 & 1.12 & 1.88 & 0.247 & 0.072 & 0.175 \\
\hline 4 & 7259 & 2.82 & 0.94 & 1.89 & 0.235 & 0.059 & 0.176 \\
\hline 5 & 8483 & 2.75 & 0.86 & 1.90 & 0.231 & 0.054 & 0.177 \\
\hline 6 & 9860 & 2.66 & 0.77 & 1.89 & 0.225 & 0.048 & 0.177 \\
\hline 7 & 11,513 & 2.60 & 0.70 & 1.90 & 0.222 & 0.043 & 0.179 \\
\hline 8 & 13,697 & 2.50 & 0.61 & 1.90 & 0.215 & 0.037 & 0.178 \\
\hline 9 & 17,228 & 2.44 & 0.55 & 1.89 & 0.212 & 0.034 & 0.178 \\
\hline 10 & 29,066 & 2.34 & 0.45 & 1.89 & 0.208 & 0.028 & 0.181 \\
\hline Total & 11,122 & 2.81 & 0.93 & 1.89 & 0.236 & 0.059 & 0.177 \\
\hline
\end{tabular}

household emissions. Fig. 2 plots unconditional average emissions by income percentile. One thing that is immediately clear is that the shape of total emissions-income relationship is dominated by the indirect emissions-income relationship, which is monotonically increasing by a sizeable amount. In contrast, direct emissions only increase slightly over the income range. Thus indirect emissions will be critical in determining the MPE, as the econometric analysis below demonstrates.

\section{Explaining household variations in per capita emissions}

It is unclear, a priori, which specific functional form will best explain the relationship between per capita emissions and per capita income.

Table 5

Sectoral contributions to the indirect and total emissions of the 1st, 5 th and 10 th deciles (\%). Source: Authors' calculations using method and data described in this section.

\begin{tabular}{|c|c|c|c|c|c|c|c|}
\hline \multirow[t]{2}{*}{ Indirect emission } & \multicolumn{3}{|c|}{$\begin{array}{l}\text { Share of total } \\
\text { emissions }\end{array}$} & \multirow[t]{2}{*}{ Total } & \multicolumn{3}{|c|}{$\begin{array}{l}\text { Share of indirect } \\
\text { emissions }\end{array}$} \\
\hline & $1 \mathrm{st}$ & 5 th & 10th & & $1 \mathrm{st}$ & 5th & 10th \\
\hline $\begin{array}{l}\text { Manufacture of food products } \\
\text { and tobacco processing }\end{array}$ & 37.4 & 25.8 & 12.7 & 22.2 & 22.9 & 20.5 & 11.3 \\
\hline Textile goods & 0.2 & 0.2 & 0.1 & 0.1 & 0.1 & 0.1 & 0.1 \\
\hline $\begin{array}{l}\text { Wearing apparel, leather, } \\
\text { furs and down }\end{array}$ & 9.4 & 11.7 & 8.9 & 10.7 & 5.8 & 9.3 & 7.9 \\
\hline Sawmills and furniture & 0.3 & 0.9 & 1.9 & 1.1 & 0.2 & 0.7 & 1.7 \\
\hline $\begin{array}{l}\text { Paper and products, printing and } \\
\text { record medium reproduction }\end{array}$ & 2.6 & 2.5 & 2.4 & 2.5 & 1.6 & 2.0 & 2.2 \\
\hline Chemicals & 12.1 & 11.9 & 10.3 & 11.8 & 7.4 & 9.4 & 9.2 \\
\hline Metal products & 0.6 & 0.6 & 0.6 & 0.7 & 0.3 & 0.5 & 0.6 \\
\hline Transport equipment & 0.9 & 2.0 & 11.8 & 4.4 & 0.5 & 1.6 & 10.6 \\
\hline Electric equipment and machinery & 1.9 & 3.9 & 6.8 & 4.8 & 1.1 & 3.1 & 6.0 \\
\hline $\begin{array}{l}\text { Electronic and telecommunication } \\
\text { equipment }\end{array}$ & 1.2 & 4.0 & 5.2 & 4.5 & 0.7 & 3.2 & 4.7 \\
\hline $\begin{array}{l}\text { Instruments, meters, cultural and } \\
\text { office machinery }\end{array}$ & 0.0 & 0.2 & 0.5 & 0.3 & 0.0 & 0.1 & 0.5 \\
\hline Jewelry & 2.7 & 2.8 & 3.1 & 3.0 & 1.7 & 2.2 & 2.7 \\
\hline Water production and supply & 2.2 & 1.5 & 0.9 & 1.3 & 1.3 & 1.2 & 0.8 \\
\hline Construction & 2.0 & 4.0 & 7.7 & 4.9 & 1.2 & 3.2 & 6.9 \\
\hline Transports and storage & 2.3 & 3.0 & 3.5 & 3.2 & 1.4 & 2.4 & 3.1 \\
\hline $\begin{array}{l}\text { Post, telecommunication and IT } \\
\text { services }\end{array}$ & 5.2 & 5.4 & 3.9 & 5.0 & 3.2 & 4.3 & 3.5 \\
\hline Eating and drinking places, and hotels & 4.0 & 5.4 & 6.9 & 6.0 & 2.5 & 4.3 & 6.1 \\
\hline Finance and insurance & 0.1 & 0.2 & 0.3 & 0.2 & 0.1 & 0.1 & 0.3 \\
\hline $\begin{array}{l}\text { Rentings and other commercial } \\
\text { services }\end{array}$ & 1.2 & 1.0 & 1.1 & 1.0 & 0.8 & 0.8 & 1.0 \\
\hline Residential and other services & 0.6 & 0.6 & 1.1 & 0.8 & 0.4 & 0.5 & 1.0 \\
\hline Education & 7.3 & 6.0 & 3.5 & 5.1 & 4.5 & 4.8 & 3.2 \\
\hline Health services and social welfare & 4.9 & 4.6 & 3.5 & 4.3 & 3.0 & 3.7 & 3.1 \\
\hline Culture, sports and entertainments & 0.9 & 1.7 & 3.3 & 2.3 & 0.5 & 1.3 & 2.9 \\
\hline
\end{tabular}

Table 6

Bivariate regression of log per capita emissions on per capita income.

\begin{tabular}{|c|c|c|c|c|c|}
\hline $\begin{array}{l}\text { Dependent } \\
\text { variable }\end{array}$ & $\begin{array}{l}\text { Log per } \\
\text { capital TC }\end{array}$ & $\begin{array}{l}\text { Log per } \\
\text { capital TC }\end{array}$ & $\begin{array}{l}\text { Log per } \\
\text { capital TC }\end{array}$ & $\begin{array}{l}\text { Log per } \\
\text { capital TC }\end{array}$ & $\begin{array}{l}\text { Log per } \\
\text { capital TC }\end{array}$ \\
\hline $\begin{array}{l}\text { Per capita } \\
\quad \text { income } / 10^{3}\end{array}$ & $\begin{array}{l}0.050 \\
{[0.001]^{* * *}}\end{array}$ & $\begin{array}{l}0.076 \\
{[0.004]^{* * *}}\end{array}$ & $\begin{array}{l}0.100 \\
{[0.002]^{* * *}}\end{array}$ & $\begin{array}{l}0.030 \\
{[0.002]^{* * *}}\end{array}$ & $\begin{array}{l}0.125 \\
{[0.003]^{* * *}}\end{array}$ \\
\hline $\begin{array}{l}\text { (Per capita } \\
\left.\quad \text { income } / 10^{3}\right)^{2}\end{array}$ & & $\begin{array}{l}-0.0005 \\
{[0.000]^{* * *}}\end{array}$ & $\begin{array}{l}-0.0013 \\
{[0.000]^{* * *}}\end{array}$ & $\begin{array}{l}-0.0002 \\
{[0.000]^{* * *}}\end{array}$ & $\begin{array}{c}-0.0018 \\
{[0.000]^{* * *}}\end{array}$ \\
\hline $\begin{array}{l}\text { (Per capita } \\
\left.\quad \text { income } / 10^{3}\right)^{3}\end{array}$ & & & $\begin{array}{l}0.000005 \\
{[0.000]^{* * *}}\end{array}$ & $\begin{array}{l}0.000001 \\
{[0.000]^{* * *}}\end{array}$ & $\begin{array}{l}0.000006 \\
{[0.000]^{* * * *}}\end{array}$ \\
\hline Constant & $\begin{array}{l}6.99 \\
{[0.010]^{* * *}}\end{array}$ & $\begin{array}{l}6.81 \\
{[0.028]^{* * *}}\end{array}$ & $\begin{array}{l}6.66 \\
{[0.012]^{* * *}}\end{array}$ & $\begin{array}{l}5.46 \\
{[0.016]^{* * *}}\end{array}$ & $\begin{array}{l}6.21 \\
{[0.015]^{* * *}}\end{array}$ \\
\hline Observations & 33,360 & 33,360 & 33,360 & 33,117 & 33,360 \\
\hline R-squared & 0.436 & 0.487 & 0.509 & 0.040 & 0.569 \\
\hline
\end{tabular}

Note: ${ }^{* * *},{ }^{* * *}$ significant at $10 \%, 5 \%, 1 \%$ respectively. Standard errors in brackets.

The Environmental Kuznets Curve (EKC) hypothesis proposes an inverted-U shaped (quadratic) relationship, for which environmental quality deteriorates during the early stages of economic development and improves only in the later stages. Whether this is actually the case is an empirical question that clearly depends on the environmental indicator, the time period and the spatial level of analysis. Early research by Shafik (1994) and Holtz-Eakin and Selden (1995) used global panel data to establish that carbon dioxide emissions did not satisfy the EKC hypothesis but were instead monotonically increasing over the relevant income range, a finding echoed by Yue et al. (2007) for Chinese provincial-level data on carbon dioxide emissions between 1985 and 1999. With these results in mind, and for numerous other reasons, there is little reason to expect that the hypothesis will hold for a cross-sectional analysis of carbon dioxide emissions at the urban household level in China. ${ }^{16}$

To allow for the possibility of a non-EKC-type relationship, we initially focused on the bivariate relationship between per capita total emissions (TC) and per capita income $(y)$ and investigated linear, quadratic and cubic models in levels, log-levels and log-logs. The transformation of TC into logs produced a far more normal distribution, justifying logs for the dependent variable. Log-levels and log-logs delivered substantially higher, and fairly similar, adjusted $\mathrm{R}^{2}$ values than the level eqs., with significant coefficients on all the income coefficients. We focus below on the log-level specification, partly for space reasons and also because the interpretation of the coefficients and their connection to the MPE is more intuitive. ${ }^{17}$ We are also interested in observing the impact of other relevant variables on emissions, and so our final model specification is:

$\operatorname{lnTC}_{k}=\beta_{0}+\beta_{1} y_{k}+\beta_{2} y_{k}^{2}+\beta_{3} y_{k}^{3}+\beta_{4} \mathbf{V}_{k}+\varepsilon_{k}$

\footnotetext{
${ }^{16}$ In particular, according to the EKC, the reduction in per capita emissions at higher levels of income is driven by changes in the composition of industry (toward less emission-intensive industries and the service sector), technological improvements (which lead to reductions in the energy- and hence emission-intensity of production) and effective policy responses to consumer demand for higher environmental quality. Within one country and at one date, however, the demand for regulation can be taken as fixed, as can the production structure and technique. Moreover, using a consumerbased approach, it is not obvious that richer individuals will choose goods that are less emission intensive (analogous to richer economies shifting toward production structures that are less emission intensive)-indeed, our results above indicate that they do not. Thus it seems quite likely that the relationship between emissions and income across individuals will have no turning point, but will rather be monotonically increasing.

${ }^{17}$ In particular, in a log-level regression the MPE is calculated by multiplying $d$ (log TC) /dy by TC evaluated at the mean levels of fitted per capita TC and income, while in a $\log -\log$ regression the MPE is calculated by multiplying $d(\log T C) / d(\log y)$ by $T C / y$. Since $T C$ is increasing over the income range, it is relatively straightforward to see the relationship between the curvature of the log-level equation and the rate of change of the MPE: if $d^{2}(\log T C) / d y^{2}$ is positive, then the MPE will be increasing with income, while if $d^{2}(\log T C) / d y^{2}$ is negative then the MPE may be either increasing or decreasing. In the log-log case, nothing definitive can be said about this relationship without seeing the data, since TC/y might be increasing or decreasing in $y$, given that TC is itself a positive function of $y$.
} 
Table 7

Determinants of per capita emissions.

Source: Author's regressions using data described in Section 2.

\begin{tabular}{|c|c|c|c|}
\hline \multirow[t]{2}{*}{ Dependent variable } & Log per capita & Log per capita & Log per capita \\
\hline & TC & DC & IC \\
\hline Per capita income $/ 10^{3}$ & $\begin{array}{l}0.093 \\
{[0.002]^{* * *}}\end{array}$ & $\begin{array}{l}0.022 \\
{[0.002]^{* * *}}\end{array}$ & $\begin{array}{l}0.116 \\
{[0.003]^{* * *}}\end{array}$ \\
\hline$\left(\text { Per capita income } / 10^{3}\right)^{2}$ & $\begin{array}{c}-0.0012 \\
{[0.000]^{* * *}}\end{array}$ & $\begin{array}{l}-0.0001 \\
{[0.000]^{*}}\end{array}$ & $\begin{array}{c}-0.0017 \\
{[0.000]^{* * *}}\end{array}$ \\
\hline$\left(\text { Per capita income } / 10^{3}\right)^{2}$ & $\begin{array}{l}0.000004 \\
{[0.000]^{* * *}}\end{array}$ & $\begin{array}{l}0.0000002 \\
{[0.000]}\end{array}$ & $\begin{array}{l}0.000006 \\
{[0.000]^{* * *}}\end{array}$ \\
\hline Number of household members & $\begin{array}{l}-0.069 \\
{[0.004]^{* * *}}\end{array}$ & $\begin{array}{l}-0.136 \\
{[0.007]^{* * *}}\end{array}$ & $\begin{array}{l}-0.043 \\
{[0.004]^{* * *}}\end{array}$ \\
\hline Household head age & $\begin{array}{l}0.001 \\
{[0.0004]^{* * *}}\end{array}$ & $\begin{array}{l}0.010 \\
{[0.001]^{* * *}}\end{array}$ & $\begin{array}{l}-0.001 \\
{[0.0004]^{* * *}}\end{array}$ \\
\hline Household head years of schooling & $\begin{array}{l}0.007 \\
{[0.001]^{* * *}}\end{array}$ & $\begin{array}{l}-0.008 \\
{[0.002]^{* * *}}\end{array}$ & $\begin{array}{l}0.014 \\
{[0.001]^{* * *}}\end{array}$ \\
\hline Household \% children (ages $0-15$ ) & $\begin{array}{l}0.010 \\
{[0.218]}\end{array}$ & $\begin{array}{l}-0.111 \\
{[0.040]^{* * *}}\end{array}$ & $\begin{array}{l}0.030 \\
{[0.030]}\end{array}$ \\
\hline Household \% elderly (age > $=65$ ) & $\begin{array}{l}0.051 \\
{[0.016]^{* * *}}\end{array}$ & $\begin{array}{l}0.119 \\
{[0.027]^{* * *}}\end{array}$ & $\begin{array}{l}0.018 \\
{[0.016]^{* * *}}\end{array}$ \\
\hline Dwelling size (square meters $/ 10^{3}$ ) & $\begin{array}{l}0.0003 \\
{[0.0001]^{* * *}}\end{array}$ & $\begin{array}{l}0.0016 \\
{[0.0002]^{* * *}}\end{array}$ & $\begin{array}{l}-0.0001 \\
{[0.0001]}\end{array}$ \\
\hline Constant & $\begin{array}{l}6.89 \\
{[0.012]^{* * *}}\end{array}$ & $\begin{array}{l}5.19 \\
{[0.016]^{* * *}}\end{array}$ & $\begin{array}{l}6.47 \\
{[0.035]^{* * *}}\end{array}$ \\
\hline Observations & 33,358 & 33,115 & 33,358 \\
\hline R-squared & 0.525 & 0.128 & 0.585 \\
\hline
\end{tabular}

Note: ${ }^{* * * * * *}$ significant at $10 \%, 5 \%$ and $1 \%$ respectively. Standard errors in brackets. Provincial dummy results not reported for space reasons.

where $\mathbf{V}$ is a vector of other variables that impact on total emissions, which include household size, the age and years of schooling of the household head, the percentages of children and elderly in the household, dwelling size and a dummy variable for each of the 15 provinces other than Beijing included in the survey data. ${ }^{18}$ In addition, we present results for the bivariate and full regressions with per capita direct emissions $(D C)$ and per capita indirect emissions (IC) as the dependent variable respectively. All data are household-level per capita values calculated using the method and data described in Section 2.

The results for the bivariate regressions are presented in Table 6. The first three columns show the linear, quadratic and cubic results for total emissions. The positive sign on the income coefficient in Column $1 \mathrm{im}-$ plies a positive monotonic relationship between per capita emissions and income, such that a one yuan increase in income is associated with an increase in total emissions of $0.17 \mathrm{~kg}$. The statistically significant negative coefficient on the quadratic term in Column 2 implies a turning point at around 71,000 yuan per capita (above which only 33 of the entire 33,360 households lie). Column 3 shows a statistically significant cubic relationship that implies two turning points: one downturn at approximately 57,000 yuan and an upturn at 115,000 yuan. The fact that the quadratic model implies an eventual downturn in per capita emissions while the cubic model implies a non-monotonic but eventually continuous rise in emissions suggests that the relatively scattered data points at the top income end are playing an overly dominant role in determining the coefficients on the quadratic and cubic terms. ${ }^{19}$ While this means that the turning points themselves cannot be taken too seriously, it should not detract from the key point that, over the vast majority of the per capita income range, Chinese household per capita total emissions are increasing.

Columns 4 and 5 present the results of the cubic model for direct and indirect emissions respectively. As observed in Fig. 2, the relationship between total emissions and income is driven almost entirely by the

\footnotetext{
18 These provinces are Anhui, Chongqing, Gansu, Guangdong, Heilongjiang, Henan, Hubei, Jiangsu, Jiangxi, Liaoning, Shandong, Shanxi, Shanghai, Sichuan and Yunnan.

${ }^{19}$ Further regressions including 4th, 5th and 6th order polynomials confirmed this point, with the inclusion of the 4th resulting in a downturn, the 5th an upturn, and the 6 th a downturn.
}

Table 8

Marginal propensities to emit at decile means (kg/yuan).

\begin{tabular}{llllll}
\hline Decile & Linear MPE & Quadratic MPE & Cubic MPE & Cubic MPDE & Cubic MPIE \\
\hline 1 & 0.057 & 0.075 & 0.098 & 0.0073 & 0.082 \\
2 & 0.065 & 0.094 & 0.108 & 0.0075 & 0.094 \\
3 & 0.070 & 0.107 & 0.116 & 0.0075 & 0.103 \\
4 & 0.076 & 0.115 & 0.124 & 0.0076 & 0.112 \\
5 & 0.083 & 0.131 & 0.131 & 0.0077 & 0.121 \\
6 & 0.091 & 0.141 & 0.140 & 0.0078 & 0.131 \\
7 & 0.101 & 0.158 & 0.150 & 0.0079 & 0.143 \\
8 & 0.116 & 0.172 & 0.162 & 0.0080 & 0.158 \\
9 & 0.144 & 0.191 & 0.177 & 0.0081 & 0.178 \\
10 & 0.270 & 0.250 & 0.180 & 0.0080 & 0.179 \\
Average & 0.099 & 0.152 & 0.147 & 0.0079 & 0.140 \\
\hline
\end{tabular}

Source: Calculated by authors based on regression results in Table 5.

relationship between indirect emissions and income, as seen by the similarity of the coefficients in Columns 3 and 5. In contrast, the relationship between per capita direct emissions and income is virtually flat. This can also be seen from the average MPE implied by the regression in Column 3, which at $0.1708 \mathrm{~kg} / \mathrm{yuan}$ is only marginally higher than the average marginal propensity for indirect emissions (MPIE) of $0.1705 \mathrm{~kg} / \mathrm{yuan}$, compared with just $0.011 \mathrm{~kg} / \mathrm{yuan}$ for the average marginal propensity for direct emissions (MPDE). While all of these imply a positive relationship between per capita emissions and income, these averages reflect the fact that the primary driver of this positive relationship is indirect, rather than direct, emission generation. We look more closely at how these marginal propensities change over the income range in the following section.

The results for the full specification are presented in Table 7. The cubic relationship continues to hold between per capita emissions and income and the inclusion of additional variables causes only minimal changes in the magnitudes on each of the income coefficients in the total and indirect emissions regressions. However, in the direct emissions regression the cubic term becomes insignificant and the squared term is only just significant. Larger households generate fewer per capita emissions on average, and this is true for both direct and indirect emissions. This implies that there are economies of scale in both direct and indirect energy consumptions, which are rather intuitive. ${ }^{20}$ The age and education level of the household head both have a significant positive impact on total emissions. Interestingly, while age impacts positively on direct emissions and negatively on indirect emissions, the reverse is true for years of schooling. At a stretch, this may suggest that more educated households are better informed about the negative (health and environmental) consequences of direct energy consumption, particularly in the form of coal, or that they are more environmentally conscious, and choose to adjust their direct energy consumption patterns accordingly. ${ }^{21}$ They are, however, perhaps unaware that their relatively "sophisticated" consumption bundles are also relatively carbon intensive. The positive coefficient on larger dwelling sizes in the total emissions regression is to be expected, and is driven by the positive impact of larger dwelling sizes on direct emissions.

The percentage of children in the household does not impact significantly on total emissions, although it does have a negative impact on direct emissions, while a higher percentage of elderly has a positive impact on all emissions. Like the age of the household head, this may indicate that older people are less aware of the health damages associated with direct energy consumption, but is more likely to reflect the longer

\footnotetext{
${ }^{20}$ For example, cooking for five people does not require five times the energy used in cooking for one person, thereby reducing per capita direct emissions. Similarly, five people in the one household might use one or two televisions, but surely not five, thereby reducing the indirect emissions associated with television consumption.

21 These thoughts on the role of education in affecting "greener" consumption choices clearly require further validation. Lenzen et al. (2006) analyze the impact of education on household energy requirement in Australia, Brazil, Denmark, India and Japan, with results that vary across countries, suggesting that the relationship between education and energy requirements is not clear cut.
} 


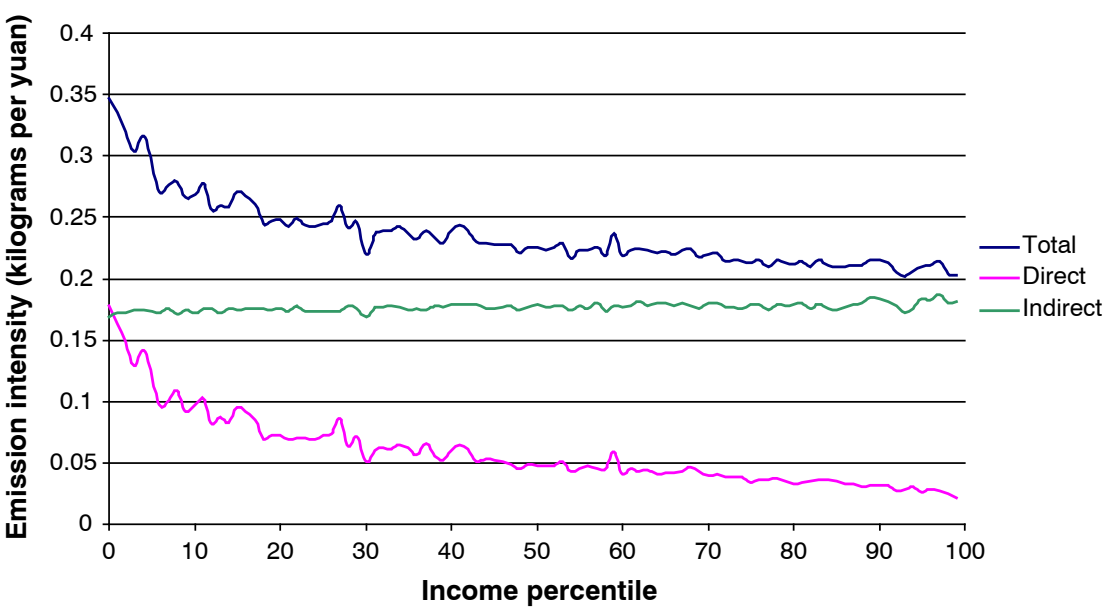

Fig 1. Per capita total, direct and indirect emission intensities across income percentiles. Source: Using method and data described in this section.

time period that retirees spend at home. The positive coefficient on the percentage of elderly in the household for the indirect emissions suggests that either their consumption bundles are relatively carbon intensive or they spend a relatively higher percentage of their income on indirect rather than direct energy.

The provincial dummy variables indicate whether each province's emissions are higher or lower than Beijing's. Twelve of the 15 provincial dummies have positive coefficients in the direct emissions regression, with just one being negative and the other two insignificant. Not surprisingly, the largest positive coefficient is on Shanxi, the country's biggest coal-producer. Of more interest are the negative and significant coefficients on all provincial dummies in both the total and indirect emissions regressions (with the exception of an insignificant coefficient for Chongqing), indicating that Beijing has the highest household emissions in the country because it has the highest indirect emissions.

\section{Income redistribution and emission reduction}

Before examining the implications of the econometric analysis, the relationship between per capita emission intensities and income established in Section 2 provides some useful preliminary insights regarding the potential impact of income redistribution on total emissions. This is not intended to demonstrate whether income redistribution would be an effective way of reducing China's emissions, but rather to understand whether the twin policy goals of reducing inequality and emissions are compatible with each other, or contradictory.

If emission intensity is constant across income classes, then it is straightforward to show that any income redistribution will have zero impact on aggregate emissions. However, if emission intensity is decreasing in income (as in our case), the impact on aggregate emissions is unclear. Intuitively, this is because transferring money from a rich person with relatively low emission intensity to a poor person with relatively high emission intensity has four effects. For the poor person, higher income reduces the emission intensity on all pre-transfer income, which contributes to a reduction in aggregate emissions, which is offset by the fact that he/she now has more income to spend. For the rich person, the income reduction increases the intensity on all pre-transfer income, which is offset by the fact that they now have less money to spend. The overall impact on aggregate emissions depends on the relative magnitudes of these terms. These relative magnitudes relate to the elasticity of the emission intensity function, which in turn relates to the marginal propensity to emit-that is, to the slope of the total emissions-income relationship (see Appendix B). In particular, it is straightforward to show that inequality-reducing income redistribution will reduce aggregate emissions as long as the MPE is increasing in income.

Based on the bivariate regressions, Table 8 provides point estimates of the MPE, MPDE and MPIE at the average level of income for each decile. The results indicate an increasing MPE, which implies that taking one yuan from someone in the richest decile and giving it

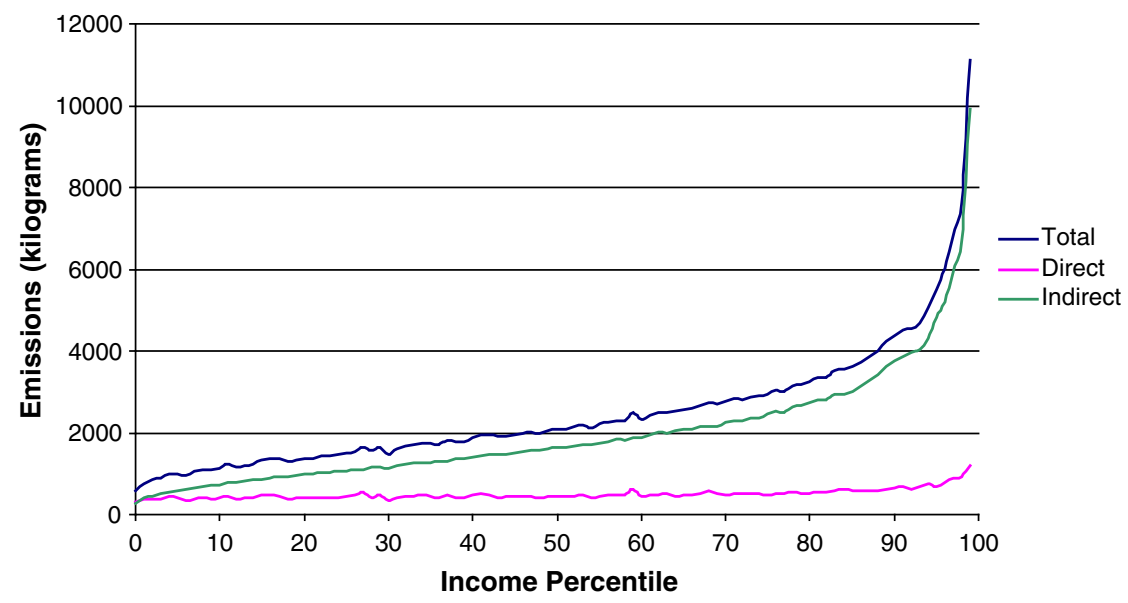

Fig. 2. Total, direct and indirect emissions across income percentiles. Source: Using method and data described in this section. 


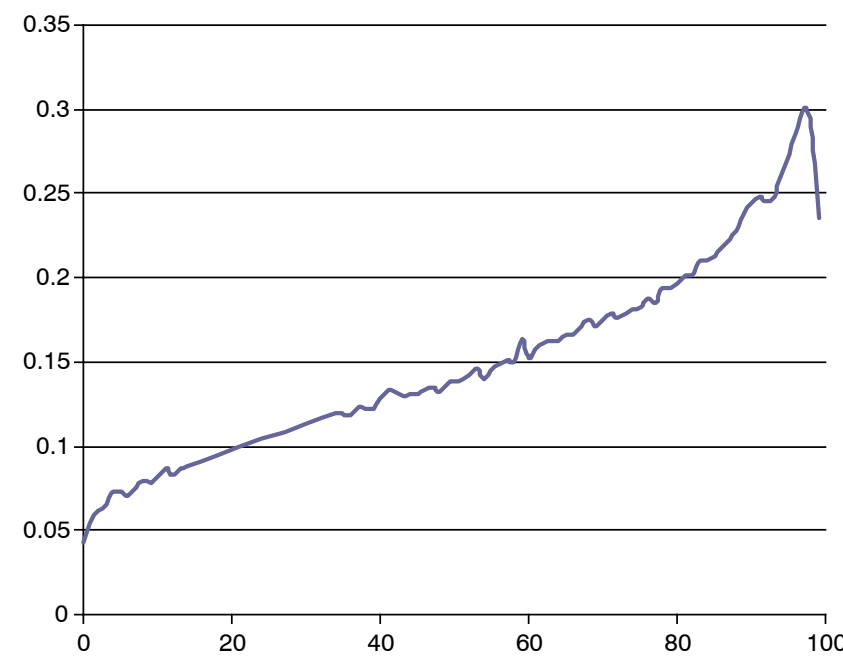

Fig. 3. MPE across income percentiles (quadratic model). Source: Based on regression results in Table 5.

to someone in the poorest decile will decrease aggregate emissions. For example, in the cubic case there will be a decrease of $0.082 \mathrm{~kg}$ $(=0.180-0.098)$. The MPE and MPIE are both increasing in income evaluated at the decile means, close to doubling between the 1 st and 10th deciles, while the MPDE rises marginally through to the 9th decile and then falls slightly in the 10th. By including indirect emissions into the analysis, our results point to the opposite conclusion of Ravallion et al. (2000) with regard to the impact of income redistribution on aggregate emissions. Namely, for the case of Chinese urban households, redistribution may well be both egalitarian and green-a win-win case.

Note, however, that the implied magnitude of emissions reductions is small. Given average per capita emissions of $2.3 \mathrm{t}$ in 2005, our finding that the MPE of households in the richest decile only differs from that of households in the poorest decile by a magnitude of less than $100 \mathrm{~g}$ suggests that the emissions-income relationship is in fact very close to linear over the relevant income range-i.e. that the MPE is very close to being constant.

Finally, it should be noted that the result is not valid for all redistributions of income from richer to poorer households. To illustrate this, Fig. 3 plots the MPE based on the quadratic model and evaluated at the percentile means of per capita income and actual TC (rather than fitted TC). This shows that the MPE for the 99th percentile is in fact below those of the 89th to 98th percentiles, such that any transfer of income from the richest to the next-to-richest people would in fact cause aggregate emissions to increase. It also shows that, for example, a transfer from someone in the 60th percentile to someone in the 59th percentile would cause aggregate emissions to increase (which demonstrates the more general point that the actual relationship between emissions and income will obviously not be a smooth fitted line). However, this should not detract from the more critical point: that income redistribution from the richest members of society to the poorest does not necessarily come at an environmental cost, and may even deliver a small gain.

\section{Conclusions}

This paper has focused on just one of the many sources contributing to China's new and unenviable position as the world's largest emitter of carbon dioxide: urban household consumption. Using urban household survey data, we examined the extent of variation in per capita energy consumption and emissions across households with different income levels. As expected, richer households emit more per capita both directly and indirectly. More interesting were the findings that poorer households are more emission intensive in their direct energy consumption because of their heavy reliance on coal, while richer households are more emission intensive in their indirect energy consumption. Our results indicated that $81 \%$ of Chinese urban household emissions in 2005 were generated indirectly through the energy inputs used in the production of goods consumed by those households. This percentage rose steadily through the income range, peaking at $89 \%$ for households in the richest decile, compared with just $61 \%$ for the poorest households. This combination of facts gave rise to a positive relationship between per capita total emissions and per capita income, driven by the rise in indirect emissions over the income range. Given that the sole purpose of all production is ultimately consumption (as Adam Smith pointed out centuries ago), a deeper understanding of the relationship between consumer choice-both between and within direct and indirect energy demand-and the emissions generated as a consequence is called for. This paper offered a small step in that direction.

Our econometric analysis confirmed that the positive relationship between total emissions and income indicated an increasing marginal propensity to emit across income deciles, which was underpinned by an increasing marginal propensity to emit indirectly over the range and a slightly increasing marginal propensity to emit directly over the first nine deciles. After controlling for income, households with larger dwellings and a higher percentage of elderly members had higher direct and indirect emissions, while households in Beijing-one of the country's most developed urban areas-had higher indirect emissions relative to 14 of the 15 other provinces in the survey data.

As Chinese household incomes continue to rise and as China's urbanization gathers pace, consumer choices are likely to follow trends established in the most developed urban cities. In combination with a rapidly aging population, evidence of an increasing MPE (even if only slight), and double-digit economic growth, it may be tempting to conclude that China's carbon dioxide emissions are on unstoppable upward trend, since all of these factors point in that direction. However, such a conclusion would be unwise based on cross-sectional results, given the potential for changes in consumer choices and production techniques. The former could be altered by the introduction of a carbon tax or changing attitudes toward "green consumption", for example. And there are a number of ways of improving the latter, including efforts to promote energy efficiency in the manufacturing sector, to strengthen international cooperation in low-carbon technologies, to reduce the emissions associated with upstream production sectors in the booming construction sector, and to conserve energy in the lighting, heating and air-conditioning at the household level (Guan et al., 2009). With all of these possibilities, the future path of the world's top carbon dioxide emitter is very difficult to pin down-or up, as the case may be.

Instead, our final conclusion is less far-reaching and more optimistic. Household-level income redistribution is certainly not an appropriate policy tool for tackling China's growing emissions-and nor did we set out to demonstrate that it was. What our results do allow us to conclude is that inequality-reducing income redistribution is unlikely to have a significantly detrimental impact on aggregate urban household carbon dioxide emissions. This is surely a positive finding for a country intent on building an environmentally friendly and harmonious society.

\section{Acknowledgments}

We would like to thank participants at the Research School of Pacific and Asian Studies (RSPAS) Seminar at The Australian National University (1 February 2011) and at the China Center for Economic Research (CCER) Seminar at Peking University (16 March 2011) for their comments and suggestions. Thanks also to Trevor Breusch for his advice, to Bruce Golley for lengthy and valuable discussions, to an anonymous referee for extremely useful comments, and especially to Glen Peters for providing the energy and emissions data. All remaining errors are the responsibility of the authors. 


\section{Appendix A. Supplementary data}

Supplementary data to this article can be found online at http://dx. doi.org/10.1016/j.eneco.2012.07.025.

\section{References}

Baiocchi, G., Minx, J., Hubacek, K., 2010. The impact of social factors and consumer behavior on carbon dioxide emissions in the United Kingdom. J. Ind. Ecol. 14 (1), 50-72.

Bin, Shui, Dowlatabadi, Hadi, 2005. Consumer lifestyle approach to US energy use and the related $\mathrm{CO}_{2}$ emissions. Energy Policy 33, 197-208.

Cohen, Claude, Lenzen, Manfred, Schaeffer, Roberto, 2005. Energy requirements of households in Brazil. Energy Policy 33, 555-562.

Druckman, A., Jackson, T., 2009. The carbon footprint of UK households 1990-2004: a socio-economically disaggregated, quasi-multi-regional input-output model. Ecol. Econ. 68 (7), 2066-2077.

Golley, Jane, Meagher, Dominic, Xin, Meng, 2008. Chinese household consumption, energy requirements and carbon emissions. chapter In: Ligang, Song, Woo, Wing Thye (Eds.), China's Dilemma: Economic Growth, the Environment and Climate Change. Asia Pacific Press, Canberra and Brookings Institution Press, Washington DC.

Guan, Dabo, Peters, Glen, Weber, Christopher, Hubacek, Klaus, 2009. Journey to world top emitter: an analysis of the driving forces of China's recent $\mathrm{CO}_{2}$ emissions surge. Geophys. Res. Lett. 36, L04709.

Heil, Mark, Selden, Thomas, 2001. Carbon emissions and economic development: future trajectories based on historical experience. Environ. Dev. Econ. 6, 63-83.

Holtz-Eakin, Douglas, Selden, Thomas, 1995. Stoking the fires? $\mathrm{CO}_{2}$ emissions and economic growth. J. Public Econ. 57, 85-101.

International Energy Agency, 2007. World Energy Outlook 2007: China and India Insights. International Energy Agency, Paris.

Kennedy, C., Steinberger, J.K., Gasson, B., Hansen, Y., Hillman, T., Havranek, M., Pataki, D.E., Phdungsilp, A., Ramaswami, A., Villalba Mendez, G., 2010. Methodology for inventorying greenhouse gas emissions from global cities. Energy Policy 38 (9), 4828-4837.

Kerkhof, Annemarie, Benders, René M.J., Moll, Henri C., 2009. Determinants of variation in household $\mathrm{CO}_{2}$ emissions between and within countries. Energy Policy 37, 1509-1517.

Kok, Rixt, Benders, René M.J., Moll, Henri C., 2006. Measuring the environmental load of household consumption using some methods based on input-output energy analysis: a comparison of methods and a discussion of results. Energy Policy 34, 2744-2761.

Lenzen, M., Dey, C., Foran, B., 2004. Energy requirements of Sydney households. Ecol. Econ. 49 (3), 375-399.

Lenzen, M., Wier, M., Cohen, C., Hayami, H., Pachauri, S., Schaeffer, R., 2006. A comparative multivariate analysis of household energy requirements in Australia, Brazil, Denmark, India and Japan. Energy 31 (2-3), 181-207.

Pachauri, Shonali, 2004. An analysis of cross-sectional variations in total household energy requirements for India using micro survey data.
Pachauri, Shonali, Jiang, Leiwen, 2008. The household energy transition in China and India. Energy Policy 36, 4022-4035.

Pachauri, Shonali, Spreng, Daniel, 2002. Direct and indirect requirements of households in India. Energy Policy 30, 511-523.

Peters, G.P., Hertwich, E.G., 2008. CO2 embodied in international trade with implications for global climate policy. Environ. Sci. Technol. 42 (5), 1401-1407.

Peters, Glen, Weber, Christopher, Lu, Jingru, 2006. Construction of Chinese energy and emissions inventory. Norwegian University of Science and Technology (NTNU), Industrial Ecology Programme (IndEcol).

Peters, G.P., Minx, J.C., Weber, C.L., Edenhofer, O., 2011. Growth in emission transfers via international trade from 1990 to 2008. Proc. Natl. Acad. Sci. 108, 8903-8908.

Ravallion, Martin, Heil, Mark, Jalan, Jyotsna, 2000. Carbon emissions and income inequality. Oxf. Econ. Pap. 52, 651-669.

Reinders, A.H.M.E., Vringer, K., Blok, K., 2003. The direct and indirect energy requirement of households in the European Union. Energy Policy 31, 139-153.

Shafik, Nemat, 1994. Economic development and environmental quality: an econometric analysis. Oxf. Econ. Pap. 46, 757-773.

Weber, C.L., Matthews, H.S., 2008. Quantifying the global and distributional aspects of American household carbon footprint. Ecol. Econ. 66 (2-3), 379-391.

Weber, Christopher, Perrels, Adriaan, 2000. Modelling lifestyle effects on energy demand and related emissions. Energy Policy 28, 549-566.

Wei, Yi-Ming, Liu, Lan-Cui, Fan, Ying, Gang, Wu., 2007. The impact of lifestyle on energy use and $\mathrm{CO}_{2}$ emission: an empirical analysis of China's residents. Energy Policy 35, 247-257.

Yue, Yaguchi, Sonobe, Tetsushi, Otsuka, Keijiro, 2007. Beyond the environmental Kuznets curve: a comparative study of $\mathrm{SO}_{2}$ and $\mathrm{CO}_{2}$ emissions between China and Japan. Environ. Dev. Econ. 12, 445-470.

\section{Glossary}

Direct emissions: Emissions generated by the consumption of direct energy either by households or sectors, measured in kilograms.

Direct energy: Energy in the form of coal, petroleum, natural gas and electricity directly consumed either by households or sectors (as direct inputs), measured in joules.

(Total, Direct or Indirect) Emission intensity: (Total, Direct or Indirect) emissions generated per yuan of output (by sector) or expenditure (per capita), measured in kilograms/ yuan.

(Total, Direct or Indirect) Energy intensity: (Total, Direct or Indirect) Energy consumed per yuan of output (by sector) or expenditure (per capita), measured in joules/yuan. Indirect emissions: Emissions generated by the consumption of indirect energy by households or sectors, measured in kilograms.

Indirect energy: Energy consumed indirectly via the energy inputs used in the production of all non-direct energy sectors that the household consumes, measured in joules. Marginal propensity to emit (MPE): Increase in emissions for a one yuan increase in income, measured in kilograms.

Total energy: Sum of direct energy and indirect energy, measured in joules. Total emissions: Sum of direct emissions and indirect emissions, measured in joules. 